\title{
SOFRIMENTO DE INDETERMINAÇÃO
}

SOFRIMENTO DE INDETERMINAÇÃO - UMA REATUALIZAÇÃO DA FILOSOFIA DO DIREITO DE HEGEL,

de Axel Honneth. Trad. Denílson Luiz Werle e Rúrion Soares. São Paulo: Esfera Pública, 2007.

JOSÉ ARTHUR GIANNOTTI

Há muitos anos funciona no Cebrap um grupo de juristas e filósofos que se reúnem para estudar filosofia do direito. Sofrimento de indeterminação, de Axel Honneth, e Democracia deliberativa (vários autores, 2007), são dois livros publicados pela editora Esfera Pública: o primeiro traduzido e o segundo organizado por Denílson Luiz Werle e Rúrion Soares Melo, dois excelentes pesquisadores desse grupo.Aqui me limito a comentar o texto de Honneth.

Como explicitam os apresentadores, numa introdução avantajada, Honneth procura reatualizar temas tratados na Filosofia do direito, de Hegel, para que sirvam de material para diagnosticar os males da vida moderna, do ponto de vista da Teoria Crítica. A primeira parte do livro, como indicam os apresentadores, reconstrói certas reflexões do jovem Hegel, que ainda em Jena, antes de publicar $A$ fenomenologia do espírito, quando aposta na reconciliação dos conflitos sociais no leito do Espírito Absoluto, espera construir uma teoria social com base numa explicação intersubjetiva da luta pelo reconhecimento, abrindo assim a possibilidade de construir o conceito de uma luta social moralmente motivada. Honneth encontra em Hegel três dimensões distintas do reconhecimento: em primeiro lugar, aquelas primárias, baseadas no "amor" e na "amizade"; em segundo, as relações jurídicas baseadas em "direitos"; $e$, finalmente, aquela que concerne à solidariedade social. No fundo, está descobrindo uma ação comunicativa que tem a philia grega como paradigma, já descrita por Aristóteles como o espelhamento de um no outro.

Honneth é explícito: retira os conceitos hegelianos do contexto da lógica hegeliana. Pergunto-me, então, o que sobra deles? Nessa reconstrução não hesita em se aproveitar de passagens de Princípios da filosofia do direito (Grundlinien der Philosophie des Rechts), publicado no 
outono de 1820, quando Hegel já dominava inteiramente seu sistema filosófico.Assiméque, para salientar "os efeitos negativos acarretados pela autonomização social das concepções em si incompletas e deficientes de liberdade", passa a "sondar progressivamente o lugar que lhes deve caber em nossa práxis significativa".

Há duas convicções de fundo que permitem a Hegel fazer uso de um tal procedimento de fundamentação indireto atrelado ao diagnóstico da época: a princípio era empiricamente indubitável que não somente aqueles dois modelos de liberdade tiveram influência poderosa no mundo social, mas também que a absolutização de cada um deles causou a primeira rejeição na autocompreensão prática dos sujeitos. Isso possibilita a Honneth, em vários lugares de seu texto, entremear referências a situações e fenômenos patológicos que podem valer como indicadores de uma transgressão das esferas legítimas do "direito abstrato" e da "moralidade"; e os conceitos com os quais ele procura caracterizar tais patologias sociais são expressões do diagnóstico da época, tais como "solidão" (\#136), "vacuidade" (\#141) ou "abatimento" (\#149), que podem ser colocados conjuntamente sob o denominador comum de um "sofrimento de indeterminação" (pp.73-74). Angústia da indecisão?

Engraçado, na Enciclopédia das ciências filosóficas em compêndio, texto de 1817 e republicado com transformações em 1930, Hegel coloca o sofrimento não ao lado da indeterminação, mas precisamente ao da determinação:

Aessência do espirito é, poresse motivo, formalmente a liberdade, a absoluta negatividade do conceito enquanto identidade consigo. Segundo essa determinação formal, ele pode abstrair de todo o exterior e de sua própria exterioridade, de seu próprio ser-aí;pode suportar a negação de sua imediatez individual, a dor (Schmerz) infinita, istoé, nessa negatividade conservarse afirmativamente, e ser idêntico para si mesmo. ${ }^{1}$

E no adendo, outras vezes o sofrimento está ligado à determinação, à fixação no particular como meio de atingir o nível do espírito.

Honneth faz Hegel dizer o contrário do que ele diz. As diferenças entre os textos de juventude e aqueles maduros não alteram o que pensa do conceito, que desde logo se apresenta como o universal se particularizando para informar-se como individual em si e para si.É nessa determinação que a dor aparece. E assim deveria ser, pois, se o Cristianismo apresenta esse movimento conceitual nos termos da Trindade, poderia Hegel dispensar o sofrimento do Calvário?

Espanta-me esse projeto de reconstruir a Filosofia do Direito de Hegel, inspirando-se em idéias sugeridas pelos textos de juventude, mas recorrendo a livros posteriores: em ambos os casos, porém, em

[1] Enciclopédia das ciências filosóficas em compêndio. Trad. Paulo Mendes. São Paulo: Edições Loyola, 1997, \#382. 
contradição direta com os textos lógicos de Hegel, quer da Lógica de Jena, quer da Enciclopédia. O que quer dizer uma "reconstrução" que não leva em conta os pilares do construído?

No fundo, tenho a impressão de que Honneth acabou sendo fascinado pela maneira como os americanos tratam a história da filosofia: um saco de gatos de onde cada um tira o argumento que lhe aprouver. $\mathrm{O}$ que pode significar um conceito hegeliano fora da lógica hegeliana? No fundo, uma palavra de uso cotidiano que foi redimensionada por Hegel e agora sofre nova reforma para caber no cadinho da Teoria Crítica. Ora, nesse plano do cotidiano uma palavra tem múltiplos sentidos, pertence a vários jogos de linguagem, de sorte que a "reconstrução" de um sistema consiste sempre numa tradução que retira desse sistema - filosófico ou científico - sua trama nervosa. Não seria mais produtivo estudar como os conceitos são empurrados para este ou aquele outro lado conforme seu uso? Em particular, conforme cada filósofo os emprega? Quem disse que "solidão" significa a mesma coisa em Hegel e em Honneth? De que serve essa invocação do magister dixit?

JOSÉ ARTHUR GIANNOTTI é professor emérito da FFLCH-USP e coordenador da área de Filosofia e Política do Cebrap. 